J. Clin. Chem. Clin. Biochem.

Vol. 18, 1980, pp. 431-432

\title{
SHORT COMMUNICATION/KURZMITTEILUNG
}

\section{A Sensitive Method for Determination of Conjugated Catecholamines in Blood Plasma}

\author{
By Marianne Nagel and H.J. Schümann \\ Pharmakologisches Institut des Universitätsklinikum \\ Essen
}

(Received October 29, 1979/March 3, 1980)

Summary: Conjugated catecholamines in blood plasma of blood donors were determined from the difference between the total and the free catecholamines. Total catecholamines were measured after complete hydrolysis of the conjugated amines (heating of acidified samples for $40 \mathrm{~min}$ at $95^{\circ} \mathrm{C}$ ). Free catecholamines were determined in untreated plasma. Determinations were performed radioenzymatically. We combined and modified the procedures of Peuler \& Johnson (1977) Life Sci 21, 625-636) and Da Prada \& Zürcher (1976) Life Sci 19, 1161-1174). The resulting method was less laborious and cheaper.

\section{Eine empfindliche Methode zur Bestimmung der konjugierten Katecholamine im Plasma}

Zusammenfassung: Die konjugierten Katecholamine im Plasma von Blutspendern wurden als Differenz zwischen de $m$ Gehalt an gesamten und freien Katecholaminen bestimmt. Nach abgeschlossener Hydrolyse der konjugierten Amine durch 40minütiges Erhitzen der sauren Proben auf $95^{\circ} \mathrm{C}$ wurden die gesamten Katecholamine gemessen. Die freien Katecholamine wurden im unbehandelten Plasma gemessen. Wir kombinierten und modifizierten die radioenzymatischen Bestimmungsmethoden von Peuler \& Johnson (1977) Life Sci 21, 625-636) and Da Prada \& Zürcher (1976) Life Sci 19,1161-1174) und erhielten ein einfacheres und billigeres Verfahren.

\section{Introductión}

Conjugated catecholamines (sulfuric and glucuronic acid conjugates) are present in urine and blood $(1,2)$. Their presence in blood is of ten ignored, although they greatly exced the free catecholamines. Thus, the greater proportion of the amines is disregarded when the estimation of the tone of the sympathetic nervous system in connexion with illnesses like hypertension or neurological disorders is based solely on the amount of the free catecholamines in blood. It therefore seems advisable to measure the conjugated as well as free catecholamines, in order to avoid misinterpretations. The methods for estimation of the conjugated amines in blood used hitherto are either too insensitive or unreliable; either the amines undergo varying degrees of destruction during hydrolysis, or hydrolysis is incomplete. The method presented here overcomes these difficulties.

\section{Experimental}

Blood samples drawn from blood donors of either sex (20-40 years) immediately after loss of $500 \mathrm{ml}$ blood were mixed with a solution ( $10 \mathrm{ml} / 1$ blood) containing $0.26 \mathrm{~mol} / 1$ dithiothreitol and $0.5 \mathrm{~mol} / 1 \mathrm{EGTA}^{1}$ ), cooled to $0^{\circ} \mathrm{C}$, and centrifuged to obtain the plasma. One part of the supernatant was used to measure free catecholamines (a). Another part $(500 \mu \mathrm{l})$ was mixed with $500 \mu 10.6 \mathrm{~mol} / 1$ perchloric acid containing $2 \mathrm{~g} / 1$ EGTA. After sedimentation of the precipitated protein the supernatant was heated to $95^{\circ} \mathrm{C}$ in Eppendorf tubes for various periods of time. After cooling, the samples were used to determine the total ( $=$ free + conjugated) amount of noradrenaline, adrenaline and dopamine (b).

Catecholamines were determined after enzymatic O-methylation, using radioactive S-adenosyl-L-methionine-methyl $\left[{ }^{3} \mathrm{H}\right]$ as methyl donor. The procedure is a simplification of previously published methods $(3,4)$. The incubation mixtures were as follows: $25 \mu$ l sample hydrolysed (a) or unhydrolysed (b), $10 \mu \mathrm{l} 0.01 \mathrm{~mol} / 1 \mathrm{HCl}$ and $25 \mu \mathrm{l}$ of a mixture consisting of $17.5 \mu \mathrm{l}$ Tris buffer ( $2 \mathrm{~mol} / \mathrm{l}$ (a) or $0.3 \mathrm{~mol} / \mathrm{l}(\mathrm{b}), 93 \mathrm{mmol} / \mathrm{l}$ $\mathrm{MgCl}_{2}, 32 \mathrm{mmol} / \mathrm{l}$ EGTA), $2 \mu \mathrm{l}$ catechol-O-methyltransferase (prepared according to (5) and further purified by Sephadex G 200 chromatography) $37 \mathrm{kBq}$ S-adenosyl-methioninemethyl[ $\left.{ }^{3} \mathrm{H}\right](18-55.5 \mathrm{~Bq} / \mathrm{mmol}), 0.05 \mathrm{mg}$ dithiothreitol and $\mathrm{H}_{2} \mathrm{O}$ up to $25 \mu \mathrm{l}$. We used $0.3 \mathrm{~mol} / \mathrm{l}$ perchloric acid or $\mathrm{H}_{2} \mathrm{O}$ as blanks. For quantitative analysis, $100 \mathrm{pg}$ noradrenaline, adrenaline and dopamine in $10 \mu 10.01 \mathrm{~mol} / 1 \mathrm{HCl}$ were added to each sample in duplicate. After incubation at $37^{\circ} \mathrm{C}$ for $1 \mathrm{~h}$ the reaction was stopped by cooling in ice-cold water. Borate buffer $(150 \mu l, 0.5 \mathrm{~mol} / 1 \mathrm{pH} 8)$, tetraphenylborate (50 $\mu 1$, $15 \mathrm{~g} / 1 \mathrm{H}_{2} \mathrm{O}$ ) and carrier (noradrenaline, adrenaline and dopamine, $0.5 \mathrm{~g} / 10.01 \mathrm{~mol} / 1 \mathrm{HCl}$ ) were added. The amines were extracted into $5 \mathrm{ml}$ diethylether. After freezing the aqueous layer the ether was transferred totally to a second set of tubes containing $0.25 \mathrm{ml} 0.1 \mathrm{~mol} / 1 \mathrm{HCl}$. After shaking and centrifugation the ether phase was discarded and the aqueous phase was washed with $5 \mathrm{ml}$ butyl acetate saturated with $\mathrm{H}_{2} \mathrm{O}$ and evaporated. The residue was dissolved in $50 \mu \mathrm{l}$ of a mixture of $80 \mathrm{ml}$ methanol and $20 \mathrm{ml} 0.001 \mathrm{~mol} / 1 \mathrm{HCl}$ and spotted on Kieselgel plates with fluorescent indicator $(5 \times 10 \mathrm{~cm}, 3$ spots/ plate). The tubes were rinsed with $25 \mu \mathrm{l}$ of the above solution. After chromatography in chloroform, ethanol, ethy lamine (70\%) (16 ml, $3 \mathrm{ml}, 2 \mathrm{ml})$ the spots with normetanephrine, metanephrine and methoxytyramine were scraped into separate scintillation vials. Normetanephrine and metanephrine were oxidized by adding $\mathrm{NH}_{4} \mathrm{OH}(1 \mathrm{ml}, 0.05 \mathrm{~mol} / \mathrm{l})$. Scintillation

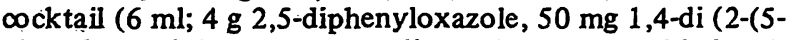
phenyloxazolyl)) benzene per liter toluene) was added and vanillin extracted into the organic phase. Methoxytyramine was dissolved in $0.5 \mathrm{ml} 0.5 \mathrm{~mol} / 1 \mathrm{HCl}$ and $7.5 \mathrm{ml}$ Quickscint 212 (Zinsser) were added.

The radioactivity was measured in a MARK II Nuclear Chicago liquid scintillation counter. The amount of free and total noradrenaline, adrenaline and dopamine and that of the conjugated part ( $=$ total - free) were determined.

For control purposes (see text) two dimensional chromatography was performed on Kieselgel plates. The usual alkaline solvent was used for the first dimension. For the second dimension, the solvent was: iso-butanol, methanol, $1 \mathrm{~mol} / \mathrm{l}$ formic acid $(10 \mathrm{ml}, 20 \mathrm{ml}, 20 \mathrm{ml})(6)$.

1) EGTA = (ethylene-bis(oxyethylenenitrilo $)$ tetraacetic acid 


\section{Results and Discussion}

During hydrolysis the amount of detectable catecholamines increased. As can be seen from figure 1 hydrolysis was complete after $40 \mathrm{~min}$. Of the catecholamines added before hydrolysis $97.1 \pm 4.7 \%$ (noradrenaline), $95.8 \pm 9 \%$ (adrenaline), and $103.4 \pm 5.5 \%$ (dopamine) $\left(\bar{x} \pm 5_{\bar{x}}, n=10\right)$ were recovered.

Table 1 shows the amounts of free and total (= free + conjugated) catecholamines in plasma samples from 10 different blood donors.

In order to affirm that the high levels of total noradrenaline, adrenaline, and dopamine found after hydrolysis were not due to methodical errors, we tested whether the amine spots were overlapped by unknown substances and whether the blank values were elevated after heating the samples. We used twodimensional chromatography for separation of the methylated catecholamines from putative unknown contaminants that might contribute to the radioactivity. $76-105 \%$ of the original amine content was found after two-dimensional chromatography. To determine blank values with a hydrolyzed sample catechol-O-methyltransferase was inhibited by $\mathrm{CaCl}_{2}$, added to the buffer in place of and at the same molarity as $\mathrm{MgCl}_{2} \cdot \mathrm{Ca}^{+}$ diminished the blank values as compared to those with $\mathrm{Mg}^{++}$. In the case of noradrenaline and adrenaline, addition of a hydrolyzed sample to the $\mathrm{Ca}^{++}$reaction mixture did not raise the blank values. The blank value for dopamine increased, but the increase was negligible compared with the number of counts obtained for dopamine after hydrolysis: 13 counts per minute compared to several hundreds of the sample (13 counts per minute $\hat{=} 0.5 \mathrm{pg}$ ).

Our results contradict those of Buu \& Kuchel (2), who stated that acidic hydrolysis at elevated temperatures is not suitable for radioenzymatic determinations of catecholamines. Their

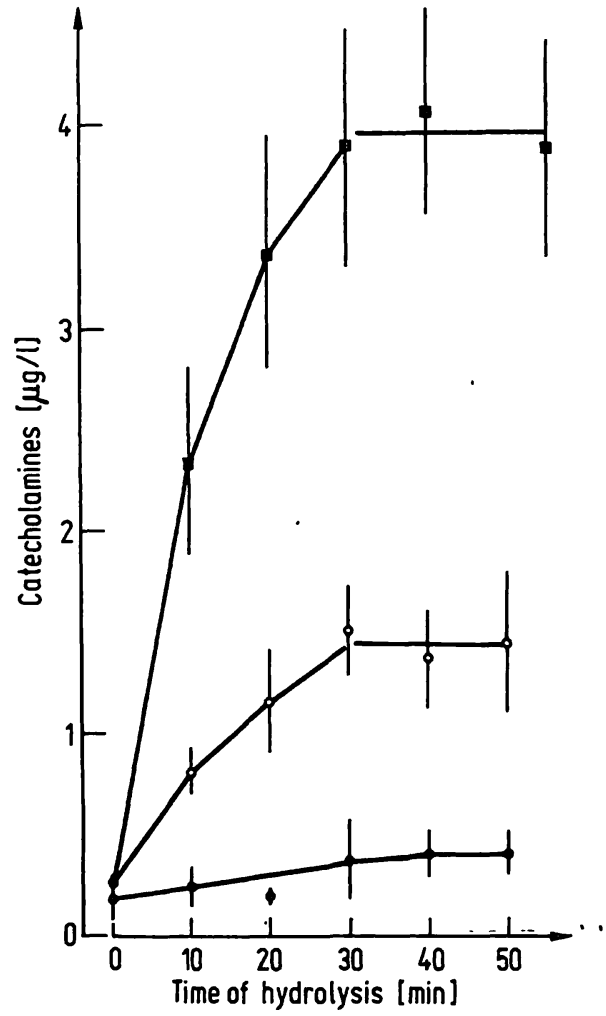

Fig. 1. Rise of detectable catecholamines with increasing time of hydrolysis.

Values are mean \pm S.E.M. of ten different plasma samples.

- Dopamine

o Noradrenaline

- Adrenaline
Tab. 1. Free and total (free + conjugated) catecholamines in plasma from blood donors immediately after loss of $500 \mathrm{ml}$ blood.

\begin{tabular}{|c|c|c|c|c|c|c|c|}
\hline \multirow{2}{*}{$\begin{array}{l}\text { Age } \\
\text { (a) }\end{array}$} & \multirow[t]{2}{*}{ Sex } & \multicolumn{2}{|c|}{$\begin{array}{l}\text { Noradrenaline } \\
\text { (ng/l) }\end{array}$} & \multicolumn{2}{|c|}{$\begin{array}{l}\text { Adrenaline } \\
\text { (ng/l) }\end{array}$} & \multicolumn{2}{|c|}{$\begin{array}{l}\text { Dopamine } \\
\text { (ng/l) }\end{array}$} \\
\hline & & free & total & free & total & free & total \\
\hline $\begin{array}{l}20 \\
31 \\
37 \\
21 \\
23 \\
26 \\
35 \\
39 \\
39 \\
40\end{array}$ & $\begin{array}{l}8 \\
8 \\
8 \\
0 \\
0 \\
0 \\
0 \\
0 \\
0 \\
0\end{array}$ & $\begin{array}{r}79 \\
416 \\
356 \\
213 \\
330 \\
345 \\
315 \\
561 \\
439 \\
206\end{array}$ & $\begin{array}{r}738 \\
683 \\
892 \\
468 \\
1106 \\
631 \\
805 \\
3017 \\
844 \\
903\end{array}$ & $\begin{array}{r}49 \\
76 \\
92 \\
79 \\
125 \\
81 \\
90 \\
81 \\
116 \\
68\end{array}$ & $\begin{array}{r}835 \\
80 \\
563 \\
\ddot{446} \\
431 \\
149 \\
1330 \\
224 \\
210 \\
204\end{array}$ & $\begin{array}{l}26 \\
53 \\
27 \\
34 \\
29 \\
27 \\
30 \\
35 \\
29 \\
36\end{array}$ & $\begin{array}{l}3533 \\
7877 \\
8413 \\
7108 \\
3095 \\
3746 \\
4422 \\
5017 \\
9423 \\
2128\end{array}$ \\
\hline \multicolumn{2}{|c|}{ Mean } & 326 & 1008 & 87.5 & 447 & 32.6 & 5476 \\
\hline \multirow{2}{*}{\multicolumn{2}{|c|}{ \pm S.E.M. }} & \pm 43 & \pm 230 & $\pm \overline{7}$ & \pm 122 & \pm 2.5 & \pm 800 \\
\hline & & \multicolumn{2}{|c|}{$\begin{array}{l}\text { conjugated: } \\
67.6 \%\end{array}$} & \multicolumn{2}{|c|}{$\begin{array}{l}\text { conjugated: } \\
80.4 \%\end{array}$} & \multicolumn{2}{|c|}{$\begin{array}{l}\text { conjugated: } \\
99.3 \%\end{array}$} \\
\hline
\end{tabular}

Plasma samples for determination of total noradrenaline, adrenaline and dopamine were heated at $95^{\circ} \mathrm{C}$ for $40 \mathrm{~min}$.

procedure of hydrolysis consists of concentrating the samples containing $0.3 \mathrm{~mol} / 1$ perchloric acid by lyophilisation. We tried their method and found it insufficiently controllable. As judged from the counts per minute for the internal standard, it appeared that in some cases most of the catecholamines were lost during the concentration process. In others the amounts of conjugated catecholamines were less than those found with our method. In other words: The time between complete hydrolysis and the start of wholesale amine destruction is not defined, whereas we determined the end of hydrolysis for our procedure precisely. Our method yielded complete hydrolysis of conjugated catecholamines without detectable destruction. It was combined with a very sensitive radioenzymatic method for the quantitative analysis of plasma catecholamines based upon previously published procedures that were combined. The result was a cheaper and less laborious method without loss of its original sensitivity.

\section{Acknowledgements}

We are obliged to Dr. W. Lubold who provided us with blood samples and to Mrs. $U$. Chebbi for her skilful technical assistance.

\section{References}

1. Häggendahl, J. (1964), Acta Physiol. Scand. 59, 255-260.

2. Buu, N. T. \& Kuchel, O. (1977), J. Lab. Clin. Med. 90, 680685.

3. Peuler, J. D. \& Johnson, G. A. (1977), Life Sci. 21, 625636.

4. Da Prada, M. \& Z̈̈rrcher, G. (1976), Life Sci. 19, 1161 1174.

5. Axelrod, J. \& Tomchick, R. (1958), J. Biol. Chem. 233, 702-705

6. Fleming, R. M. \& Clark, W. G. (1970), J. Chromatogr. 52, $305-312$

Prof. Dr. med. H. J. Schümann Direktor des Pharmakologischen Instituts Hufelandstraße 55 D-4300 Essen 